\title{
ETOMIDATE, ALFATHESIN AND THIOPENTONE AS INDUCTION AGENTS FOR CORONARY ARTERY SURGERY
}

\author{
Joerg Tarnow, Wolfgang Hess and Walter Klein
}

\begin{abstract}
In 24 premedicated patients about to undergo coronary artery bypass surgery, anaesthesia was induced with either etomidate $0.3 \mathrm{mg} \cdot \mathrm{kg}^{-1}$, alfathesin $0.07 \mathrm{ml} \cdot \mathrm{kg}^{-1}$ or thiopentone 3.0 $\mathrm{mg} \cdot \mathrm{kg}^{-1}$, in combination with fentanyl. Detailed haemodynamic studies were made including measurements of arterial pressure, right atrial pressure, pulmonary artery and pulmonary capillary wedge pressure, heart rate, cardiac output and monitoring of the lead $\mathrm{V}_{5}$ electrocardiogram. Cardiovascular data were recorded in the awake patient and one, three and five minutes after induction of anaesthesia. Following fentanyl $0.01 \mathrm{mg} \cdot \mathrm{kg}^{-1}$ and suxamethonium $1.0 \mathrm{mg} \cdot \mathrm{kg}^{-1}$ the trachea was intubated and further measurements were made immediately and five minutes after intubation. Induction of anaesthesia using the new non-barbiturate agent etomidate was associated with a remarkable cardiovascular stability. No major changes in heart rate, arterial blood pressure, cardiac index, pulmonary artery pressure, right and left ventricular filling pressure or total peripheral resistance occurred. The addition of fentanyl decreased heart rate and cardiac index slightly and was associated with a significant reduction of the rate-pressure product. The cardiovascular effects of thiopentone were very similar to those of etomidate, except for a small increase in heart rate with thiopentone. Alfathesin produced a significant fall in arterial pressure, cardiac index and stroke index, while heart rate increased. The rate-pressure product remained unchanged. The combination of alfathesin with fentanyl produced an additional decrease in blood pressure and cardiac index.

None of the three induction procedures was associated with cardio-vascular stimulation during laryngoscopy and tracheal intubation. Our findings suggest that either thiopentone or etomidate combined with fentanyl are acceptably safe in cardiac patients while alfathesin with fentanyl appears to be more detrimental to the circulation.
\end{abstract}

AMONG the newer intravenous induction anaesthetics the non-barbiturate etomidate has been advocated for induction of general anaesthesia ${ }^{1,2}$, since preliminary reports have suggested minimal cardiovascular depression following intravenous administration in dogs and in man. However, previous studies of the haemodynamic effects of etomidate in man have only been done either in patients with a normal cardiovascular system $^{3.4,6.7}$ or in already anaesthetized subjects 5 . In this study, therefore, etomidate was used for induction of anaesthesia in patients with ischaemic heart disease who were to undergo coronary artery bypass operations. The results were compared with the haemodynamic effects of standard doses of alfathesin and thiopentone.

\section{Material and Methods}

Twenty-four patients, ASA class III, ranging in age from 38 to 67 years were studied. Written informed consent was obtained from each of the

Joerg Tarnow, M.D., Associate Professor; Wolfgang Hess, M.D. . Assistant Professor; Walter Klein, M.D. Research Fellow, Department of Anaesthesiology, Free University of Berlin, Charlottenburg Clinic, Spandauer Damm 130, 1 Berlin 19, Germany. patients at the time of the preoperative visit. Preoperative clinical features are given in Table I, including some angiographic and diagnostic catheterisation data and the number of coronary artery bypass grafts which were done. Coronary artery lesions were regarded as significant when the degree of narrowing was more than 70 per cent. Maintenance anti-anginal therapy consisted of sublingual nitroglycerin, long-acting nitrates (isosorbidinitrate $60-120 \mathrm{mg} / \mathrm{day}$ per os) and propranolol ( $40-240 \mathrm{mg} /$ day per os). The daily oral maintenance dose of glycosides was $0.2-0.4$ $\beta$-acetyl-digoxin. The last single dose of these drugs was given 12 to 16 hours before operation. The patients were premedicated with meperidine $1.0 \mathrm{mg} \cdot \mathrm{kg}^{-1}$, promethazine $0.5-1.0 \mathrm{mg} \cdot \mathrm{kg}^{-1}$ and atropine $5-10 \mu \mathrm{g} \cdot \mathrm{kg}^{-1}$ intramuscularly $90 \mathrm{~min}$ utes before induction of anaesthesia. Systemic blood pressure was measured continuously through an 18-gauge cannula inserted percutaneously into a radial artery under local anaesthesia. With the aid of continuous electrocardiographic and intravascular pressure monitoring, a $7 \mathrm{~F}$ triple-lumen Swan-Ganz flow directed catheter was placed in the pulmonary artery through the right internal jugular vein under local anaes- 
TABLE I

Clinical Features

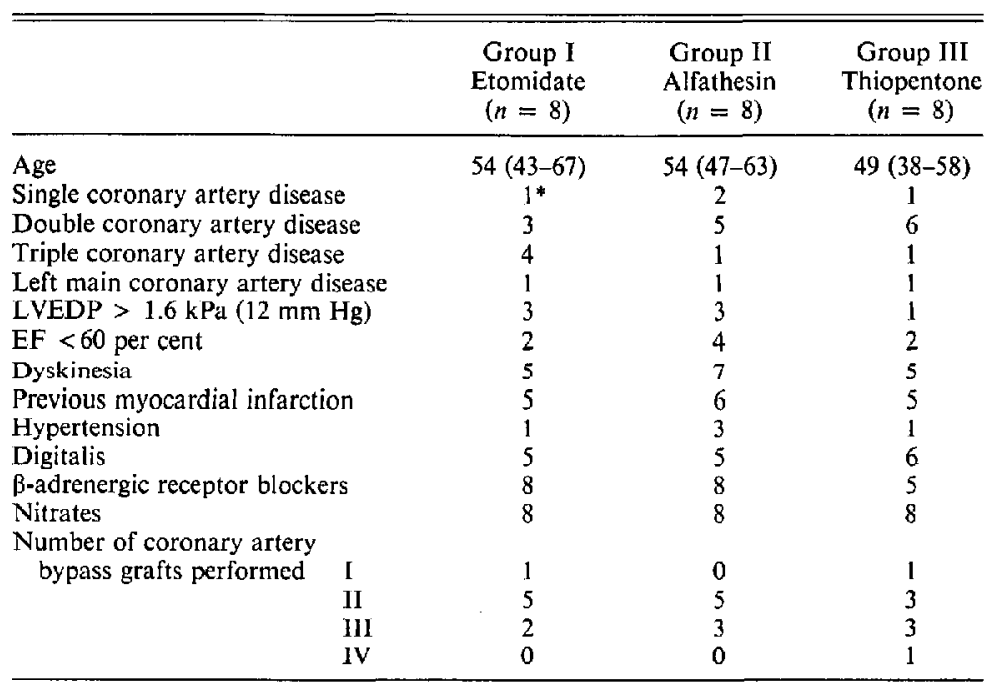

*Number of patients.

thesia. This catheter was used for measuring right atrial (RAP), pulmonary artery (PAP) and pulmonary capillary wedge pressure (PCW). All pressures were measured using Statham $P 23 \mathrm{db}$ transducers placed at the level of the mid-axillary line and were recorded, together with a lead $V_{5}$ of the electrocardiogram on a Hellige EK 21 eightchannel recorder and display oscilloscope. Heart rate (HR) was calculated from the electrocardiographic tracing. Cardiac output was measured by a thermodilution technique, using a Fischer BN 7206 computer. A bolus of $10 \mathrm{ml}$ of five per cent dextrose, at $5-10^{\circ} \mathrm{C}$, was injected rapidly into the right atrium. The resulting temperature-time curve was monitored on a calibrated Goerz Servorgor-M recorder. Arterial and mixed venous blood gases were measured using an AVL 938 blood gas analyzer. From the measured variables, the following data were derived: Cardiac index $(\mathrm{Cl})$ by dividing cardiac output $(\mathrm{CO})$ by the body surface area and stroke volume index (SVI) by dividing $C I$ by heart rate. Total peripheral resistance (TPR), pulmonary vascular resistance (PVR), right and left ventricular stroke work index (RVSWI, LVSWI) were calculated using the formulae:

$$
\begin{gathered}
\text { TPR }=(A \overline{\mathrm{P}}-\mathrm{RA} \overline{\mathrm{P}} / \mathrm{CO}) \times 80 \\
\mathrm{PVR}=(\mathrm{PA} \overline{\mathrm{P}}-\overline{\mathrm{PC}} \overline{\mathrm{W}} / \mathrm{CO}) \times 80 \\
\mathrm{RVSWI}=(1.36(\mathrm{PA} \overline{\mathrm{P}}-\mathrm{RA} \overline{\mathrm{P}}) / 100) \times \mathrm{SVI} \\
\mathrm{LVSWI}=(1.36(\mathrm{~A} \overline{\mathrm{P}}-\overline{\mathrm{PC}}) / 100) \times \mathrm{SVI}
\end{gathered}
$$

The heart rate-systolic blood pressure product was used as an index of myocardial oxygen demand. ${ }^{8}$

The patients were allowed to rest for about 15 minutes after the cannulation procedure before a series of control measurements was taken, which included repeated measurements of the cardiac output by thermal dilution until two consecutive readings were within five per cent. The induction drugs were then injected into a peripheral vein over 30 seconds: etomidate $0.3 \mathrm{mg} \cdot \mathrm{kg}^{-1}(8 \mathrm{pa}-$ tients), alfathesin $0.07 \mathrm{ml} \cdot \mathrm{kg}^{-1}$ (8 patients), and thiopentone $3.0 \mathrm{mg} \cdot \mathrm{kg}^{-1}$ (8 patients) respectively. Three measurements at two minute intervals were made over a period of five minutes, during which the patients breathed spontaneously. Then fentanyl $0.01 \mathrm{mg} \cdot \mathrm{kg}^{-1}$ and suxamethonium $1.0 \mathrm{mg} \cdot \mathrm{kg}^{-1}$ were added and the trachea was intubated. Further measurements were made immediately (within $30 \mathrm{sec}$ ) following tracheal intubation and five minutes later under conditions of controlled ventilation. $\left(\mathrm{FI}_{0_{2}}=1.0\right.$ ), using a Draeger-Spiromat ventilator. The mean changes at one minute, three minutes and at the end of the observation period were compared with the control values in the awake patients and tested for statistical significance using Student's t-test for correlated data. To analyse the haemodynamic effects of laryngoscopy and tracheal intubation, the variables obtained immediately following intubation were compared 
with the pre-intubation values obtained at five minutes. Statistical significance was defined as $\mathrm{p} \leq 0.05$. Data are presented as means $\pm \mathrm{SEM}$.

\section{RESUlts}

All of the patients lost consciousness with the induction drugs used in this study. Etomidate and thiopentone caused little changes in systolic, diastolic and in mean arterial pressure ( -7.2 and -3.5 per cent, respectively; Figures 1, 2). Induction of anaesthesia using alfathesin was associated with a significant fall in BP (19.6 per cent) which, however, did not exceed $20 \mathrm{~mm} \mathrm{Hg}$ before administration of fentanyl. but decreased further after the addition of fentanyl. There was no increase in blood pressure following tracheal intubation in any group. Cardiac indices (Figure 2) decreased only slightly during the initial stage of induction. Following fentanyl, cardiac indices fell significanlly compared with the control values in the awake patients, the lowest CI values being measured in the alfathesin/fentanyl group $\left(2.25 \mathrm{I} / \mathrm{min} \cdot \mathrm{m}^{2},=-33.2\right.$ per cent $)$.

In contrast to alfathesin and thiopentone (both agents increased heart rate by about 10 beats/min), etomidate failed to alter heart rate significantly (Figure 3). Addition of fentanyl decreased heart rate in all groups. No stimulating effect of the intubation procedure was observed. Due to their influence on heart rate, thiopentone and alfathesin reduced stroke index more than etomidate (Figure 3). Arrhythmias or additional ischaemic electrocardiographic changes did not occur.

None of the three induction agents exerted major effects on mean pulmonary artery pressure or on left and right ventricular filling pressure (Figure 4). The increase in right atrial pressure following intubation was due to the mechanical effects of artificial ventilation.

Total peripheral resistance (Figure S) remained largely unaffected in all three groups. Alfathesin and etomidate caused moderate biphasic changes in pulmonary vascular resistance (Figure 5) which returned to the control values within the observation period. Only small changes of the PVR occurred in the thiopentone group.

Left ventricular stroke work index (Figure 6) decreased slightly following induction of anaesthesia using etomidate/fentanyl and thiopentone/fentanyl ( 5.6 per cent and 16.9 per cent respectively). Alfathesin/fentanyl was associated with a $\mathbf{4 9 . 6}$ per cent fall in LVSWI. Right ven-

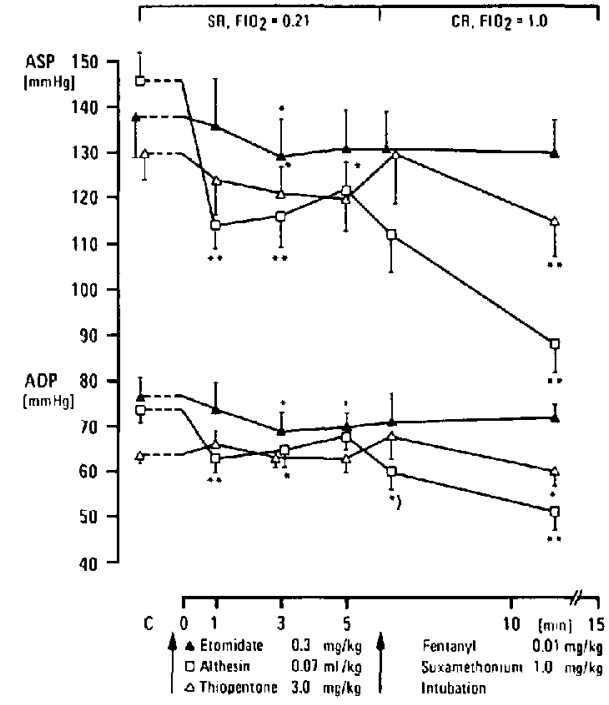

FICURE 1 Changes in systolic and diastolic arterial pressure (means \pm SEM) during induction of anaesthesia with etomidate/fentanyl $(n=8)$, alfathesin/fentanyl $(n=8)$ and thiopentone/fentanyl $(n=8) . C=$ controls (awake patients). $\mathrm{SR}=$ spontaneous respira tion; $\mathrm{CR}=$ controlled ventilation. ${ }^{*} \mathrm{P}<0.05$, ${ }^{*}{ }^{*} \mathrm{P}<$ 0.01 (compared with control value). $* P<0.05$ (post intubation value was compared with the pre-intubation value obtained at the fifth minute).
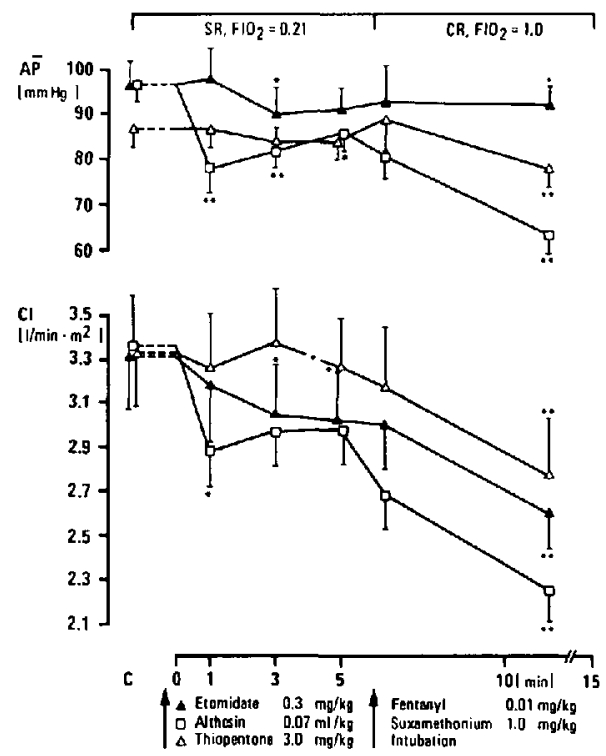

Figure 2 Changes in mean arterial pressure and cardiac index (means \pm SEM) during induction of anaesthesia with etomidate/fentanyl $(n=8)$, alfathesin/fentanyl $(n=8)$ and thiopentone/fentanyl $(n=8)$. For abbreviations and symbols, see Figure 1 . 

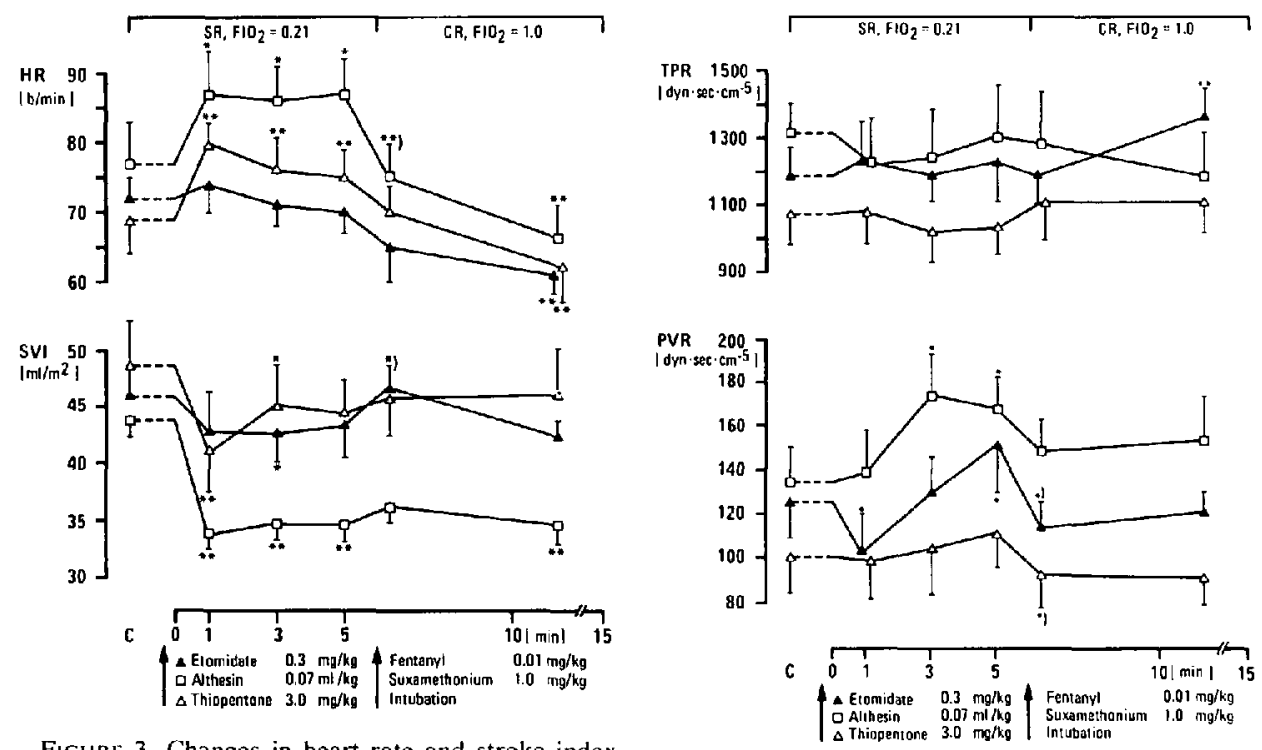

FIgure 3. Changes in heart rate and stroke index (means $\pm S E M)$ during induction of anaesthesia with etomidate/fentanyl $(n=8)$, alfathesin/fentanyl $(n=8)$ and thiopentone/fentanyl $(n=8)$. For abbreviations and symbols, see Figure 1 .

FIGURE 5 Changes in total peripheral resistanceand pulmonary vascular resistance (means \pm SEM) during induction of anaesthesia with etomidate/fentanyl $(n=$ $8)$, alfathesin/fentanyl $(n=8)$ and thiopentone/fentanyl $(n=8)$. For abbreviations and symbols, see Figure 1 .
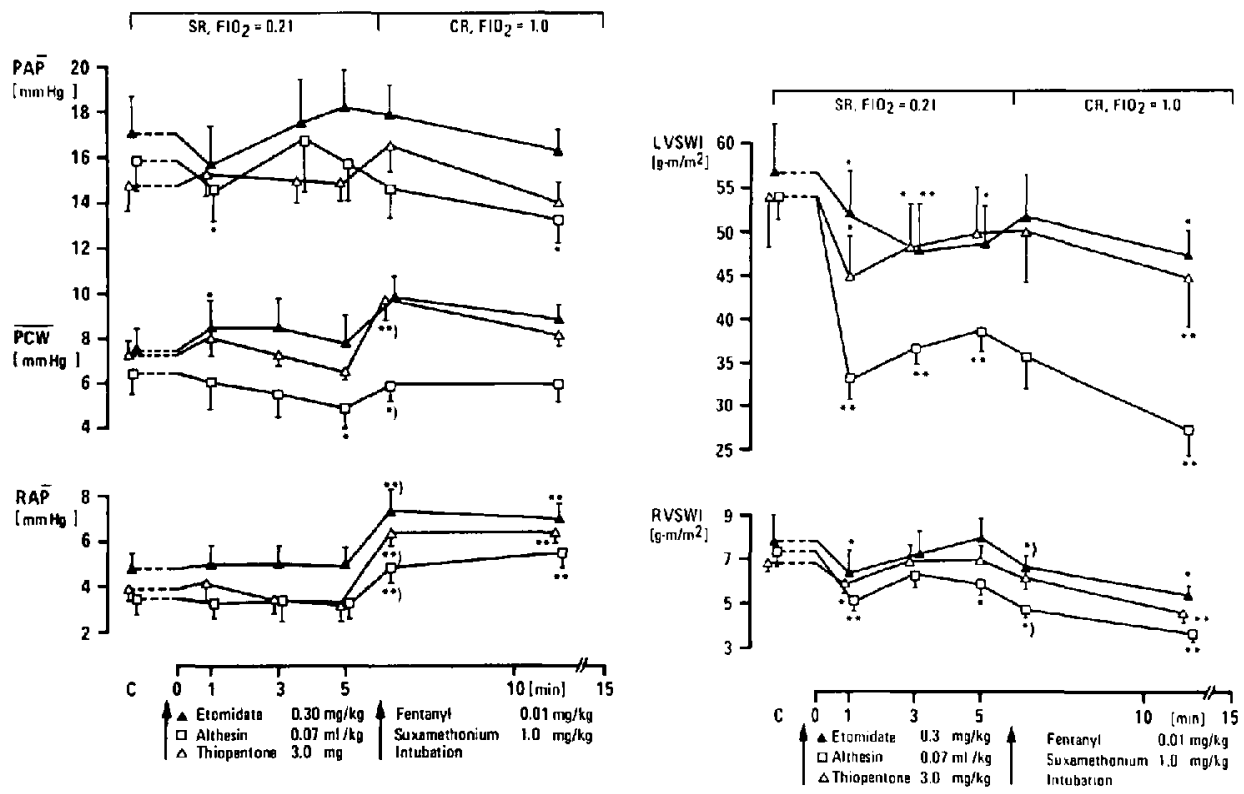

Figure 4 Changes in mean pulmonary artery pressure, mean pulmonary capillary wedge pressure and mean right atrial pressure (means $\pm S E M$ ) during induction of anaesthesia with etomidate/fentanyl $(n=8)$, alfathesin/fentanyl $(n=8)$ and thiopentone/fentanyl $(n=8)$. For abbreviations and symbols, see Figure 1 .

Figure 6. Changes in left and right ventricular stroke work index (means \pm SEM) during induction of anaesthesia with etomidate/fentanyl $(n=8)$, alfathesin/fentanyl $(n=8)$ and thiopentone/fentanyl $(n=8)$. For abbreviations and symbols, see Figure 1. 

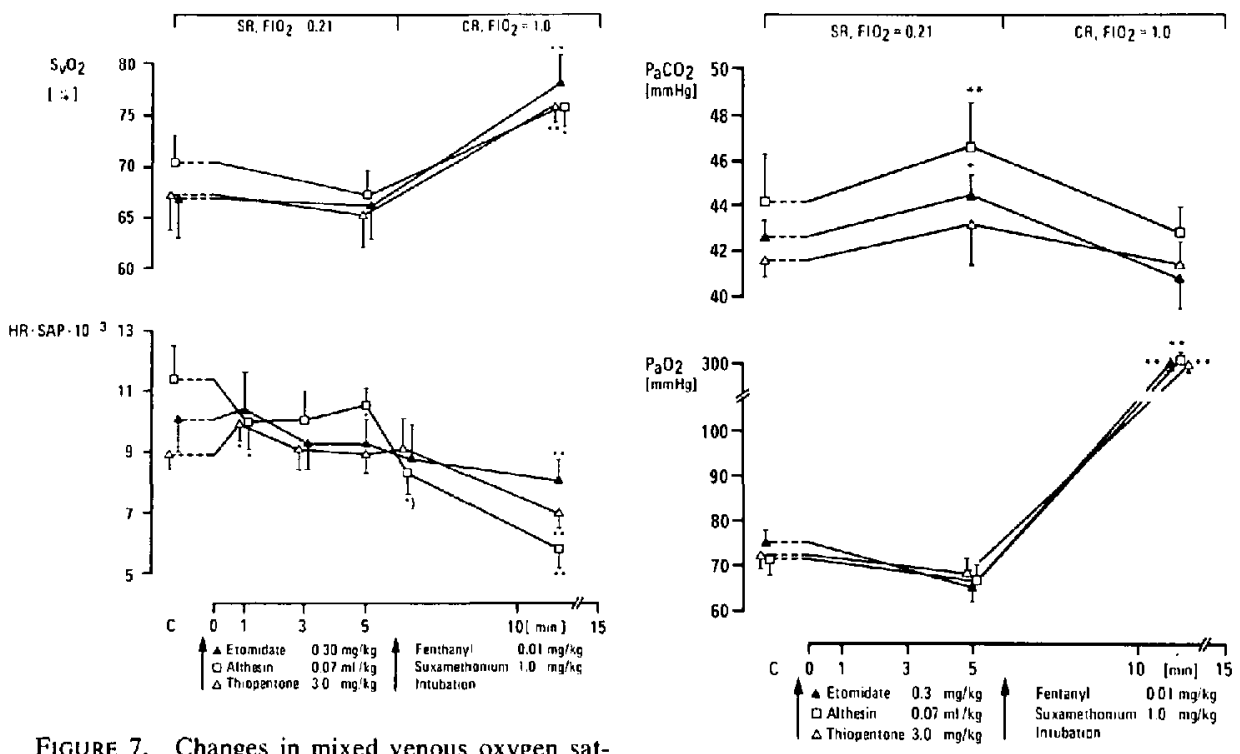

FIGURE 7. Changes in mixed venous oxygen saturation and in the rate-pressure product (means \pm SEM) during induction of anaesthesia with etomidate/fentanyl $(n=8)$, alfathesin/fentanyl $(n=8)$ and thiopentone/fentanyl $(n=8)$. For abbreviations and symbols, see Figure $t$.

tricular stroke work index (Figure 6) was slightly reduced in each group.

Mixed venous oxygen saturations (Figure 7) did not change significantly during the initial induction phase and increased when controlled ventilation using 100 per cent oxygen was instituted, suggesting an adequate oxygen supply to the body as a whole. The heart rate-systolic blood pressure product, an indirect index of myocardial oxygen consumption, changed only little with etomidate and thiopentone before the administration of fentanyl and decreased significantly after the addition of fentanyl (20 and 21.7 per cent, respectively). Induction of anaesthesia using alfathesin/fentanyl reduced myocardial oxygen demand by 49 per cent (Figure 7). None of the three agents produced changes in carbon dioxide tension and $\mathrm{Pa}_{\mathrm{O}_{2}}$ always exceeded 7.98 $\mathrm{kPa}(60 \mathrm{~mm} \mathrm{Hg})$.

\section{Discussion}

Induction of anaesthesia in patients undergoing coronary artery bypass operations is a hazardous procedure because these patients are less tolerant of decreases in coronary artery perfusion pressure and increases in myocardial oxygen demand. Since cardiovascular surgery is expand-

FIGURE 8. Changes of the arterial blood gas values (means \pm SEM) during induction of anaesthesia with etomidate/fentanyl $(n=8)$, alfathesin/fentanyl $(n=8)$ and thiopentone/fentanyl $(n=8)$. For abbreviations and symbols, see Figure 1.

ing, the need for an induction agent which lacks cardiovascular side effects is well appreciated. Consequently it is useful to consider what effects some of the drugs recently recommended as alternative induction agents may have on important determinants of myocardial oxygen supply and demand.

Etomidate is a new non-barbiturate agent dissolved in propylene glycol. Some of the features which are important for clinical use include short duration of action, lack of analgesic properties and freedom from histamine release ${ }^{9,10}$. Preliminary reports have suggested cardiovascular stability following intravenous administration in dogs and in physically fit human volunteers. ${ }^{4,6,7,11}$

The results of this study demonstrate that, in patients with severe ischaemic heart disease, etomidate produced only small cardiovascular effects which are supposed merely to reflect the physiological change from the waking to the sleeping state. Our data also indicate that addition of fentanyl results in small decreases in heart rate and a moderate fall in cardiac index. No changes in cardiovascular dynamics occurred in association with laryngoscopy and tracheal intubation, which is known frequently to stimulate the prime determinants of myocardial oxygen 
demand by reflex sympathetic discharge. The lack of cardiovascular changes during laryngoscopy and intubation is supposed to be due mainly to the relatively large doses of fentanyl. The lack of response to this stimulus may also reflect a fair degree of beta adrenergic blockade, although propranolol was discontinued 12 to 15 hours before the study. Previously reported disadvantages associated with the use of etomidate, such as pain on injection and the occurrence of myoclonia, ${ }^{1,2}$ were not observed in our study, which is probably due to the use of the new solvent propylene glycol instead of water and to the use of generous premedication in our patients.

A comparative study of induction agents should imply the use of equipotent dosage. While potency of inhalation anaesthetics is fairly well determined by the MAC values, no convincing method of defining the potency of intravenous induction drugs has been developed so far. In our study, therefore, we used standard clinical doses of the anaesthetics investigated. On this basis the cardiovascular effects of etomidate and thiopentone were very similar, except for the small increase in heart rate which occurred with thiopentone. This finding agrees with that of Broadley and Taylor, ${ }^{12}$ who also found no major cardiovascular effects during induction with thiopentone $2.5 \mathrm{mg} \cdot \mathrm{kg}^{-1}$ in patients undergoing cardiac surgery. We could not confirm the results of Sonntag, et al. ${ }^{13}$ who described marked increases in heart rate after thiopentone 4.0 $\mathrm{mg} \cdot \mathrm{kg}^{-1}$ which were associated with highly significant decreases in stroke volume and a 55 per cent rise of myocardial oxygen consumption in healthy volunteers. These differences are supposed to be due to the fact that the majority of our patients were pretreated with $\beta$-receptor blocking agents and digitalis and that all were premedicated.

Induction of anaesthesia with alfathesin caused relatively marked haemodynamic pertubations, producing a more pronounced fall in mean arterial pressure ( 19.6 per cent), cardiac index (14 per cent) and stroke index ( 23 per cent) than was observed with etomidate or thiopentone. Although the control haemodynamic data for each group are comparable, the historical data presented do not exclude the possibility that the alfathesin group had poorer ventricular function (more patients with decreased ejection fraction and documented dyskinesia), which may have contributed to our findings. In general, the results of our study agree with those of others ${ }^{12,14-17}$ who studied the effects of comparable doses of al- fathesin in patients with cardiac pathology. The addition of fentanyl produced further cardiovascular depression but, on the other hand, probably helped to prevent an increase in myocardial oxygen demand during laryngoscopy and tracheal intubation, as observed by Campbell, et al., ${ }^{14}$ Savege, et $a .^{18}$ and Prys-Roberts, ef al. ${ }^{19}$ who have used alfathesin as the sole induction agent.

Our findings differ from those of Sonntag, et al.,$^{20}$ who observed a 21 per cent increase in cardiac index and a 50 per cent increase in myocardial oxygen consumption as a consequence of increased heart rate after alfathesin $0.075 \mathrm{ml} \cdot \mathrm{kg}^{-1}$. They concluded that the drug is contraindicated in patients with impaired coronary blood flow reserve. However, it should be noted that the patients in those studies were healthy young volunteers who had received no premedication or any other drugs, such as $\beta$ receptor blockers.

In conclusion, our study shows that either thiopentone or etomidate with fentanyl were acceptably safe in cardiac patients while alfathesin/fentanyl appeared to be more detrimental to the circulation.

\section{REFERENCES}

1. Gooding, J.M. \& Corssen, G. Etomidate: an ultrashort-acting nonbarbiturate agent for anesthesia induction. Anesth. Analg. 55: 286 (1976).

2. Fragen, R.J., Caldwell, N. \& Brunner, E.A. Clinical use of etomidate for anesthesia induction: a preliminary report. Anesth. Analg. 55: 730(1976).

3. Brueckner, J.B., Gethmann. J.W., Patschke, D., Tarnow, J. \& Weymar. A. Untersuchungen zur Wirkung von Etomidate auf den Kreislauf des Menschen. Anaesthesist 23: 322 (1974).

4. Gooding, J.M. \& Corssen, G. Effect of Etomidate on the cardiovascular system. Anesth. Analg. 56: 717 (1977).

5. Hempelmann, G., Hempelmann, W. \& PiepenBrock, S. Die Beeinflussung der Blutgase und Hämdynamik durch Etomidate bei myokardial vorgeschädigten Patienten. Anaesthesist 23: 423 (1974).

6. Kettler, D., Sonntag, H. \& Donath, U. Haemodynamik, Myokardmechanik, Sauerstoffbedarf und Sauerstoffversorgung des menschlichen Herzens unter Narkoseeinleitung, mit Etomidate. Anaesthesist 23: 116 (1974).

7. Rifat, K., Gamulin, Z. \& Gemperle, M. Etomidate: effets cardiovasculaires du nouvel agent anesthesique intraveineux. Canad. Anaesth. Soc. J. 23: 492 (1976).

8. Nelson, R.R., Goebel, F.L., Jorgensen, C.R., WANG, K., Wang, Y, \& TAYLOR, H.L. Hemadynamic predictors of myocardial oxygen consumption during static and dynamic exercise. Circulation 50: 1179(1974).

9. Janssen, P.A.J., Niemeegers, C.J.E., Schelle- 
KENS, K.H.L. \& LENAERTS, F.M. Etomidate, $R-(+)$-ethyl-1-1-( $\alpha$-methyl-benzyl)-imidazole-5carboxylate ( $\mathrm{R} 16659$ ), a potent, short-acting relatively atoxic intravenous hypnotic agent in rats. Drug Res. 21: 1234 (1971).

10. Doenicke, A., Lorenz, W. Beigl, R. Bezency, H., Uhlig, G., Kalmar, L., Praetorius, B. \& MANN, G. Histamine release after intravenous application of short-acting hypnotics. A comparison of Etomidate, Althesin (CT 1341) and Propanidid. Br. J. Anaesth. 45: 1097 (1973)

11. Weymar, A., Elgenheer, F. Gethmann, J.W., Reinecke, A., Patschke, D., Tarnow, J. \& BrüCKNER, J.B. Tierexperimentelle Untersuchungen zur Wirkung von Etomidate auf den Kreislauf und die myokardiale Sauerstoffversorgung. Anaesthesist 23: 150 (1974).

12. BRoadLEy, J.N. \& TAYLOR. P.A. An assessment of althesin for the induction of anaesthesia in cardiac surgical patients: a comparison with thiopentone. Br. J. Anaesth. 46: 687 (1974).

13. Sonntag, H., Hellegerg, K., Schenk, H.D., Donath, U., Regensburger. D., Kettler, D. Duchanova, H. \& Larsen, R. Effects of thiopental on coronary blood flow and myocardial metabolism in man. Acta Anaesth. Scand. 19:69 (1975).

14. Campeell, D., Forrester, A.C., Miller, D.C., HutTon, I., KenNedY, J.A., LAWRIE, T.D., LoRIMER, A.R. \& MCCALL, D. A preliminary clinical study of CT 1341, a steroid anaesthetic agent. Br. J. Anaesth. 43: 14(1971)

15. Harrison, S.G.C. \& Sellick, B.A. Cardiovascular effects of Althesin in patients with cardiac pathology. Br. J. Anaesth. 44: 1205 (1972).

16. LYONS, S.M. \& CLARKE, R.S. A comparison of different drugs for anaesthesia in cardiac surgical patients. Br. J. Anaesth. 44: 575 (1972).

17. Savege, T.M., Colvin, M.P., Weaver, E.J., BOND, C., DRAKE, J. \& INNISS, R. A comparison of some cardiorespiratory effects of althesin and ketamine when used for induction of anaesthesia in patients with cardiac disease. Br. J. Anaesth. 48: 1071 (1976)

18. Savege, T.M., Foley, I.E., Ross, L. \& MaxWELL, M.P. A comparison of the cardiorespiratory affects of althesin with thiopentone and methohexitone. Postgrad. Med. J. (Suppl. 2) 48: 66 (1972).

19. Prys-Roberts, C.. Fö̈x, P. \& Biro, G.P. Cardiovascular responses of hypertensive patients to induction of anaesthesia with Althesin (CT 1341). Postgrad. Med. J. (Suppl. 2) 48: 80 (1972)

20. Sonntag, H., Schenk, H.D., Regensburger. D., Kettler, D., HellaerG, K., Knoll, D., DONATH, U. \& BECKER, H. Effects of althesin (CT 1341) en coronary blood fow and myocardial metabolism in man. Acta Anaesth. Scand. 17: 218 (1973).

RËSUMÉ

Chez 24 patients devant subir un pontage aorto-coronarien, on a utilisé après prémédication (mépéridine $1 \mathrm{mg} \cdot \mathrm{kg}^{-1}$, prométhazine $0.5-1 \mathrm{mg} \cdot \mathrm{kg}^{-1}$ et atropine $5-10 \mu \mathrm{g} \cdot \mathrm{kg}^{-1} 90$ minutes auparavant), comme agent d'induction l'éthomidate $\left(0.3 \mathrm{mg} \cdot \mathrm{kg}^{-1}\right)$, l'alfathésin $(0.07$ $\left.\mathrm{ml} \cdot \mathrm{kg}^{-1}\right)$ ou le thiopental $\left(3 \mathrm{mg} \cdot \mathrm{kg}^{-1}\right)$, en association avec le fentanyl. Une étude hémodynamique détaillée a été effectuée. Elle incluait les mesures des pressions artérielle systolique, auriculaire droite, pulmonaire et pulmonaire bloquée, de la fréquence et du débit cardiaque, ainsi que du monitoring de la dérivation V5 de l'ECG. On a effectué ces mesures chez le patient ćveillé. puis une, trois et cinq minutes après l'induction de l'anesthésie. Après une dose de fentanyl $\left(0.01 \mathrm{mg} \cdot \mathrm{kg}^{-1}\right)$ et de succinylcholine $\left(1 \mathrm{mg} \cdot \mathrm{kg}^{-1}\right)$, on a procédé à l'intubation et une nouvelle série de mesures a été effectuée cinq minutes plus tard.

Une stabilité cardiovasculaire remarquable a été observée dans les inductions avec le nouvel agent non barbiturique étomidate. On n`a observé aucun changement majeur de la fréquence cardiaque, des pressions de remplissage droite et gauche, ainsi que de la résistance périphérique. Après addition de fentanyl, on a constaté un ralentissment léger de la fréquence el du débit cardiaque, ainsi qu'une diminution significative du produit fréquence pression.

Les effets cardiovasculaires du thiopental étaient très similaires à ceux de l'étomidate si ce $n$ 'est d'une légère augmentation de la fréquence cardiaque après l'injection de ce barbiturique. Quant à l'alfathésin, il a causé une chute significative de la pression artérielle, de l'index cardiaque et de l'index d'éjection, avec une augmentation de la fréquence cardiaque. Le produit fréquence-pression demeurait inchangé. L'addition de fentanyl contribuait à diminuer davantage la pression artérielle et l'index cardiaque.

Aucune des trois méthodes étudiées n'a été associée avec une stimulation cardiovasculaire durant la laryngoscopie et l'intubation. Nos travaux suggèrent que l'éthomidate ou le thiopental associés au fentanyl sont acceptables au point de vue sécurité des cardiaques, alors que l'alfathésin avec le fentanyl semble affecter davantage la circulation. 